\title{
A Comparative Analysis of Students' Attitudes and Interests in Science Subjects
}

\author{
Zurweni $^{1}$, Dwi Agus Kurniawan ${ }^{2 *}$, Miftahul Zannah Azzahra ${ }^{2}$ \\ ${ }^{1}$ Department of Chemistry Education, Universitas Jambi, Indonesia \\ ${ }^{23}$ Department of Physics Education, Universitas Jambi, Indonesia \\ *Corresponding email: dwiagus.k@unja.ac.id
}

Received: 28 July 2021

Accepted: 27 August 2021

Published: 27 August 2021

Abstract: A Comparative Analysis of Students' Attitudes and Interests in Science Subjects. Objective: This research was conducted with the aim of knowing the comparison of attitudes and interests and the relationship between students' attitudes and interests towards science subjects with fermented material. Methods: This research uses quantitative methods with associative and comparative research types. Findings: the results of the T test with a value of sig. (2-tailed) $<0.05$ and the results of the correlation test between attitudes and students' interests in science subjects with fermented material obtained the results of the correlation test with the value of sig. (2-tailed) $<0.05$. Conclusion: Based on the t-test there are differences in students' attitudes and interests towards science subjects with fermentation material at SMPN 8 Batanghari and MTsN Batanghari 6. and MTsN 6 Batanghari

Keywords: attitude, interest, fermentation, Biology, Science.

Abstrak: Analisis Perbandingan Sikap dan Minat Siswa pada Mata Pelajaran IPA. Tujuan: Penelitian ini dilakukan dengan tujuan untuk mengetahui perbandingan sikap dan minat serta hubungan antara sikap dan minat siswa terhadap mata pelajaran IPA dengan materi fermentasi. Metode: Penelitian ini menggunakan metode kuantitatif dengan jenis penelitian asosiatif dan komparatif. Temuan: didapatkan hasil uji $T$ dengan nilai sig. (2-tailed) <0,05 dan didapatkan hasil uji korelasi antara sikap dan minat siswa pada mata pelajaran IPA dengan materi fermentasi diperoleh hasil uji korelasi dengan nilai sig.(2-tailed) < 0,05. Kesimpulan: Berdasarkan uji-t terdapat perbedaan sikap dan minat siswa terhadap mata pelajaran IPA dengan materi fermentasi di SMPN 8 Batanghari dan MTsN Batanghari 6. Berdasarkan hasil uji korelasi terdapat hubungan antara sikap dan minat siswa pada mata pelajaran IPA dengan materi fermentasi di SMPN 8 Batangha ri dan MTsN 6 Batanghari.

Kata kunci: sikap, minat, fermentasi, Biologi, IPA.

\section{To cite this article:}

Zurweni, Kurniawan, D. A., \& Azzahra, M. Z. (2021). A Comparative Analysis of Students' Attitudes and Interests in Science Subjects. Jurnal Pendidikan Progresif, 11(2), 290-308. doi: 10.23960/ jpp.v11.i2.202112. 


\section{INTRODUCTION}

Education is a process of changing one's attitudes and behavior through teaching and training. Education is a matter of human life that is useful for improving the nation's standard of living and growing in students good morals to invest in human character (Alan \& Afriansyah, 2017; Rahmawati, 2018; Syukri et al., 2019). Education is an important thing and cannot be separated from human life (Duygu et al., 2018; Parker, 2019; Prajapati et al., 2017). The implementation of the 2013 curriculum is the government's effort to produce a superior generation (Susilowati, 2017; Nenotaek et al., 2019; Novalinda et al., 2020). The 2013 curriculum is the next step in developing a competency-based curriculum in the form of integrated attitudes, knowledge and skills.

The 2013 curriculum is a curriculum that prioritizes understanding, skills and character education. The 2013 curriculum is a curriculum that requires students to play an active role in the learning process (Richardo \& Richardo, 2016; Hidayati et al., 2020; Kurniawan, 2021). The 2013 curriculum is important to be implemented in Indonesia because the younger generation of Indonesia needs to be prepared in the competence of attitudes, skills, and knowledge (Reswari, 2018; Kustijono \& Wiwin HM, 2014; Wulandari, 2020). The 2013 curriculum is a learning system that can provide meaningful and broad experiences to students (Fellner, 2018; Loudon, 2019; Sofyan, 2019). The existence of educational standards aims to advance education in various fields, such as in the field of natural sciences.

Natural science is a term used to refer to a family of sciences where the objects are natural objects with definite and general laws. Natural Science is a basic science that plays an important role in the development of science and technology (Giorgi, 2019; Kelleher \& Tierney, 2018; Yuliati \& Lestari, 2019). What is studied in science is cause and effect, the causal relationship of events that occur in nature (Maison et al., 2020; Tri Pudji Astuti, 2019; Utaminingsih et al., 2018). Science subjects at the SMP/MTs level in the national curriculum include: Physics, biology, chemistry, and earth and space sciences (Cooper \& Berry, 2020; Imaduddin \& Khafidin, 2018; Wulandari, 2020). Biology is a part of natural science.

Biology is the study of living things, namely humans, animals and plants. Biology is one of the sciences that plays an important role regarding life with the environment regarding the scope of biology and the branches of biological sciences in it which are arranged methodically and systematically related to each other. (Imaduddin $\&$ Khafidin, 2018). Biology is the science that studies the diversity of living things (Da Silva et al., 2015; Furqaani et al., 2017; Ilmu, 2019). Biology, part of Natural Sciences (IPA) puts forward the aspects of minds on, hands on, and hearts on (Maknun et al., 2020; Susanti \& Djukri, 2018). One of the materials that will be studied in biology subjects is fermentation. Fermentation is an important innovation by mankind and this process is used to convert organic substrates into useful products (Kumar et al., 2019).

Student attitudes are one of the factors that influence the learning process that comes from within students (Dewi et al., 2017; Maison et al., 2018; Rahayu \& Romadona, 2020). Indicators of student attitudes towards science include indicators of social implications for science, adoption of scientific attitudes, enjoyment of learning science and interest in increasing time to learn science (Astalini et al., 2018; Putra et al., 2019; Tanti et al., 2020). The pleasure in learning science is the students' love for learning science which is upheld by high curiosity. Basically, there 
are still uncertainties about attitudes and teaching approaches, taken from the many scientific attitudes that must be applied in studying science (Sabrina, 2017; Astalini et al., 2018; Tamjid, 2018 ). The first thing that can be seen from students liking or disliking physics is how students behave during the lesson. Student attitudes in learning in the form of positive attitudes and negative attitudes.

Interest is a feeling that can give enthusiasm in doing something. Interest is as attention or inclination and desire or liking to be interested in something without being asked (Astuti, 2017; Kawet, 2017; Meganingtyas et al., 2019). Learning is related to interest that interest is one aspect of psychology that can encourage someone to achieve certain goals such as encouraging students to easily obtain material presented by the teacher so that they can increase knowledge and experience.(Fauziyah \& Triyono, 2020; R. H. Nasution et al., 2020; Wibowo, 2017). To improve conceptual understanding, interest in learning is needed and the right way of learning, low interest in learning is the cause of the nonoptimal learning achievement achieved by students where interest in learning is the tendency of individuals to get pleasure without pressure (Nur Laila \& Eriyanto, 2020; Permatasari et al., 2019). Having an interest in a particular subject makes students have a positive attitude towards that lesson.

This research is in line with research (Riwahyudin, 2015; Nursa'adah, 2014), in this study the results obtained that attitudes and interests affect student learning outcomes. Due to the lack of students' understanding of science subjects with fermented material, this research needs to be carried out to find out how students' attitudes and interests are towards science subjects with fermented material. Based on the explanation above, this research aims to solve threefold:

1. How is the comparison between the attitudes of students in grades VII A and VII B at SMPN 8 Muaro Jambi and MTsN 6 Batanghari towards science subjects with fermentation material?

2. How is the comparison between the interests of students in grades VII A and VII B at SMPN 8 Muaro Jambi and MTsN 6 Batanghari towards science subjects with fermentation material?

3. How is the relationship between students' attitudes and interest in science subjects with fermentation material?

\section{- METHODS \\ Research design and procedures}

This research uses quantitative methods with associative and comparative research types. by filling out a questionnaire. Quantitative research is one type of research whose specifications are systematic, well-planned, and clearly structured from the beginning to the making of the research design. (Nugroho, 2018). This type of associative research is research that is asking for the relationship between two or more variables (Sulfemi \& Luthfianti, 2019).

In data collection, the first activity that must be done is to select students based on the categories given by the researcher, then provide a questionnaire on student attitudes in science subjects, and interest questionnaires in science subjects. Then the questionnaire data was processed using the SPSS application. The use of the SPSS application functions to view descriptive statistics, in the form of mean, min, max, percentage, and category of students ((Pramesti, 2018; Santoso, 2019; Wahyuni, 2020)). The data needed in research can be collected or obtained from various data sources. The procedures for collecting data in this study are in accordance with the following diagram: 


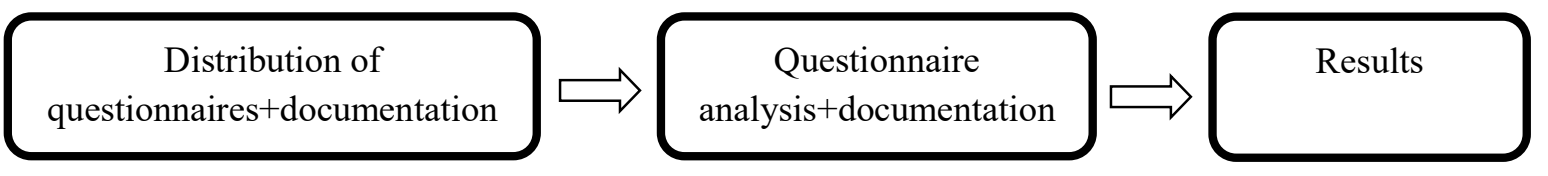

Figure 1. Research procedure

\section{Population and sample}

The sample in this study was 148 students from SMPN 8 Batanghari and MTsN 6 Batanghari in Batanghari district. The sampling technique is purposive sampling. Purposive sampling is a sampling technique with certain considerations or special selection (Jannah et al., 2021). The subjects taken were class VIIA and VII B consisting of 80 women and 68 men.
The description of the sample in this study, namely students of class VII A and VII $B$ at SMPN 8 Batanghari and MTsN 6 Batanghari are as follows:

\section{Research Instruments}

The instrument in this study used an attitude questionnaire and an interest questionnaire, for the attitude questionnaire

Table 1. Research sample

\begin{tabular}{|c|c|c|c|c|c|c|c|c|c|c|}
\hline \multirow[t]{3}{*}{ No } & \multirow[t]{3}{*}{ School name } & \multirow{3}{*}{$\begin{array}{l}\text { Total } \\
\text { students }\end{array}$} & \multicolumn{4}{|c|}{ Attitude } & \multicolumn{4}{|c|}{ Interest } \\
\hline & & & \multicolumn{2}{|c|}{ VIII A } & \multicolumn{2}{|c|}{ VIII B } & \multicolumn{2}{|c|}{ VIII A } & \multicolumn{2}{|c|}{ VIII B } \\
\hline & & & $\mathbf{L}$ & $\mathbf{P}$ & $\mathbf{L}$ & $\mathbf{P}$ & $\mathbf{L}$ & $\mathbf{P}$ & $\mathbf{L}$ & $\mathbf{P}$ \\
\hline 1. & SMP Negeri 8 Batanghari & 74 & 17 & 20 & 17 & 20 & 17 & 20 & 17 & 20 \\
\hline 2. & MTsN 6 Batanghari & 74 & 17 & 20 & 17 & 20 & 17 & 20 & 17 & 20 \\
\hline
\end{tabular}

there were 18 statement items, which were divided into positive statements totaling 9 items and negative statements totaling 9 items while for the interest questionnaire there were 6 statement items, divided into positive statements totaling 3 items and negative statements totaling 3 items. The focus of this research is on 2 dimensions of attitude and 2 dimensions of interest with attitude indicators, the social implications of science there are nine statements and there are nine statements of interest in a career in science. Then the indicators used to measure student interest are attention in learning there are theree statements and the feeling of happiness there are theree statements on this instrument using a Likert scale. The scale consists of 5 points with a value of strongly agree is 5 , agree is 4 , neutral is 3 , disagree is 2 , and strongly disagree is 1 which was adapted from research (Kurniawan et al., 2018). The questionnaire grid can be seen in table 2 and table 4.

Table 2. Grid of students' attitude questionnaires in science subjects with fermentation material

\begin{tabular}{cll}
\hline NO. & \multicolumn{1}{c}{ Statements } & Indicator \\
\hline 1. & Using money for science lessons is a good thing & \\
\hline 2. & $\begin{array}{l}\text { Public money spent on science in recent years has been } \\
\text { used wisely }\end{array}$ & \\
\hline 3. & $\begin{array}{l}\text { The government should facilitate more for science } \\
\text { research }\end{array}$
\end{tabular}




\begin{tabular}{|c|c|c|}
\hline 4. & Science makes life better & \multirow{6}{*}{$\begin{array}{l}\text { social implications } \\
\text { of science }\end{array}$} \\
\hline 5. & Science is man's worst enemy. & \\
\hline 6. & The discovery of science does more harm than good & \\
\hline 7. & $\begin{array}{l}\text { Too many laboratories have been built at the expense of } \\
\text { education }\end{array}$ & \\
\hline 8. & This country spends too much money on science & \\
\hline 9. & Money spent on science research is wasted & \\
\hline 10. & $\begin{array}{l}\text { When I graduate from school, I want to work with people } \\
\text { who are making discoveries in science }\end{array}$ & \multirow{9}{*}{$\begin{array}{l}\text { interest in a career in } \\
\text { science }\end{array}$} \\
\hline 11. & $\begin{array}{l}\text { I don't like working in a science lab after I graduate } \\
\text { school }\end{array}$ & \\
\hline 12. & $\begin{array}{l}\text { Working in a science lab is an interesting way to make a } \\
\text { living }\end{array}$ & \\
\hline 13. & I want to teach science when I graduate from school & \\
\hline 14. & Work as a scientist will be interesting & \\
\hline 15. & I don't want to be a scientist after I finish school & \\
\hline & $\begin{array}{l}\text { Working in the science field will be boring and always } \\
\text { boring }\end{array}$ & \\
\hline 17. & Work as a scientist will be boring & \\
\hline & $\begin{array}{l}\text { I don't like being a scientist because it requires too much } \\
\text { education. }\end{array}$ & \\
\hline
\end{tabular}

Due to the student attitude questionnaire on science subjects with fermentation material using a Likert scale consisting of 5 categories, there are intervals in each category, and the intervals in each category can be seen in table 3. The description of the category of student attitudes in science subjects with fermentation material is as follows:

Table 3. Categories of student attitudes in science subjects with fermentation material

Indicator Interval

Category

Social implications of science Interested in a career in science

\begin{tabular}{ccc}
\hline Very Not Good & $7-12.6$ & $7-12.6$ \\
\hline Not good & $12.7-18.2$ & $12.7-18.2$ \\
\hline Enough & $18.3-23.8$ & $18.3-23.8$ \\
\hline Good & $23.9-29.4$ & $23.9-29.4$ \\
\hline Very good & $29.5-35$ & $29.5-35$ \\
\hline
\end{tabular}

The description of the student interest instrument grid for science subjects with fermentation material is shown in Table 4. Due to the attitude questionnaire of students in science subjects with fermentation material using a Likert scale consisting of 5 categories, there are intervals in each category, and the intervals in each category can be seen in table 5 . 
Table 4. Student interest questionnaire instruments in science subjects with fermentation material

\begin{tabular}{clll}
\hline NO. & \multicolumn{1}{c}{ Statements } & Indikator \\
\hline 1. & $\begin{array}{l}\text { I listen well when the teacher is explaining the physics } \\
\text { subject }\end{array}$ & $\begin{array}{c}\text { attention in } \\
\text { learning }\end{array}$ \\
\cline { 1 - 2 } 2. & $\begin{array}{l}\text { I understand all of the teacher's explanations from start to } \\
\text { finish in the ongoing physics learning process }\end{array}$ & $\begin{array}{c}\text { feeling of } \\
\text { happiness }\end{array}$ \\
\cline { 1 - 2 } 3. & I don't pay attention when physics class is in progress & I feel interested in the physics subject matter being taught \\
\hline 5. & I like the physics subject that is taught & $\begin{array}{l}\text { I am not enthusiastic in following the physics lessons } \\
\text { taught }\end{array}$ &
\end{tabular}

The description of the category of student interest in science subjects with fermentation material is shown in Table 5.

\section{Data Analysis Technique}

In this study using quantitative data analysis with SPSS 25, to look for descriptive statistics and inferential statistics. According to (Muchson, 2017; Rasyad, 2003) Descriptive statistics is a science which is a collection of rules regarding the collection, estimation, and drawing conclusions from statistical data to describe a problem, the information that can be obtained by descriptive statistics includes

Table 5. Categories of student attitudes in science subjects with fermentation material

\begin{tabular}{ccc}
\hline \multirow{2}{*}{ Category } & \multicolumn{2}{c}{ Indicator Interval } \\
\cline { 2 - 3 } & Attention in learning & Feeling happy \\
\hline Very Not Good & $4-7.2$ & $5-9$ \\
\hline Not good & $7.3-10.4$ & $10-13$ \\
\hline Enough & $10.5-13.6$ & $14-17$ \\
\hline Good & $13.7-16.8$ & $18-21$ \\
\hline Very good & $16.9-20$ & $22-25$ \\
\hline
\end{tabular}

data concentration (mean, median, mode), data distribution ( range, mean deviation, variance and standard deviation), the tendency of a data set, the size of the location (quartiles, deciles and percentiles). In this study, the researcher used the mean, median, and mode to find out information based on descriptive statistics. Inferential statistics are statistics relating to how to draw conclusions based on data obtained from samples to describe the characteristics or characteristics of a population (Astri et al., 2013). In this study, before testing the hypothesis, a prerequisite test is first carried out. The prerequisite test is a test that must be taken in order to choose the right testing technique for proving the research hypothesis (Setiawan \& Aden, 2020). Prerequisite tests carried out in this study were linearity test, homogeneity test and normality test. The data is said to be linear if the value of $\mathrm{Sig}<0.05$, the data is said to be homogeneous if the value of sig $>0.05$ while the data is said to be normal if the value of sig. $>0.05$. Furthermore, after the prerequisite 
test is carried out, the $\mathrm{T}$ test and correlation test can be carried out. T test is used to determine the comparison between variables with a value of $\operatorname{sig}<0.05$ while the correlation test is used to determine the relationship between variables with a value of $\operatorname{sig}<0.05$.

\section{- RESULTS AND DISCUSSION}

Descriptive analysis of attitude and interest

Descriptive statistics is the statistics section regarding data collection, presentation, determination of statistical values, making diagrams or pictures about something, here the data is presented in a form that is easier to understand or read. (Nasution, 2017). Descriptive statistical analysis was carried out by describing all data from all variables in the form of a frequency distribution (Soleh \& Zainiyati, 2020).

The following describes the results of descriptive statistics on student attitudes and student interest variables in science subjects with fermented material, which results will be obtained from the distribution of questionnaires in grades VII A and VII B at SMPN 8 Batanghari and MTsN 6 Batanghari. The description of the results for the variables of students' attitudes towards science subjects with fermentation material for grades VII A and VII B at SMPN 8 Batanghari and MTsN 6 Batanghari on indicators of social implications of science is shown in the table below: The description of the results for the variables of students' attitudes towards science subjects with fermentation material for grades VII A and VII B at SMPN 8 Batanghari and MTsN 6 Batanghari on the indicators of interest in a career in science is shown in the table below:

In the results of the descriptive statistical test of the attitude variable, there are two indicators. In the first indicator, namely social implications of science, it was found that at

Table 6. Descriptions of students' attitudes towards science subjects with fermentation material on indicators of social implications of science

\begin{tabular}{|c|c|c|c|c|c|c|c|c|c|}
\hline \multicolumn{2}{|c|}{ Student response } & Interval & $\mathbf{F}$ & $\%$ & Category & Mean & Med & Min & Max \\
\hline \multirow{10}{*}{$\begin{array}{c}\text { SMPN } 8 \\
\text { Batanghari }\end{array}$} & \multirow{5}{*}{$\begin{array}{c}\text { VII } \\
\text { A }\end{array}$} & $7.0-12.6$ & 1 & $2.7 \%$ & Very Not Good & \multirow{5}{*}{3.3784} & \multirow{5}{*}{3} & \multirow{5}{*}{1} & \multirow{5}{*}{5} \\
\hline & & $12.7-18.2$ & 4 & $10.8 \%$ & Not good & & & & \\
\hline & & $18.3-23.8$ & 14 & $37.8 \%$ & Enough & & & & \\
\hline & & $23.9-29.4$ & 16 & $43.2 \%$ & Good & & & & \\
\hline & & $29.5-35.0$ & 2 & $5.4 \%$ & Very good & & & & \\
\hline & \multirow{5}{*}{$\begin{array}{l}\text { VII } \\
\text { B }\end{array}$} & $7.0-12.6$ & 0 & $0 \%$ & Very Not Good & \multirow{5}{*}{3.4865} & \multirow{5}{*}{3} & \multirow{5}{*}{2} & \multirow{5}{*}{5} \\
\hline & & $12.7-18.2$ & 3 & $8.1 \%$ & Not good & & & & \\
\hline & & $18.3-23.8$ & 18 & $48.6 \%$ & Enough & & & & \\
\hline & & $23.9-29.4$ & 11 & $29.7 \%$ & Good & & & & \\
\hline & & $29.5-35.0$ & 5 & $13.5 \%$ & Very good & & & & \\
\hline \multirow{10}{*}{$\begin{array}{l}\text { MTsN } 6 \\
\text { Batanghari }\end{array}$} & \multirow{5}{*}{$\begin{array}{c}\text { VII } \\
\text { A }\end{array}$} & $7.0-12.6$ & 0 & $0 \%$ & Very Not Good & \multirow{5}{*}{3.6757} & \multirow{5}{*}{4} & \multirow{5}{*}{2} & \multirow{5}{*}{5} \\
\hline & & $12.7-18.2$ & 4 & $10.8 \%$ & Not good & & & & \\
\hline & & $18.3-23.8$ & 12 & $32.4 \%$ & Enough & & & & \\
\hline & & $23.9-29.4$ & 13 & $35.1 \%$ & Good & & & & \\
\hline & & $29.5-35.0$ & 8 & $21.6 \%$ & Very good & & & & \\
\hline & \multirow{5}{*}{$\begin{array}{c}\text { VII } \\
\text { B }\end{array}$} & $7.0-12.6$ & 0 & $0 \%$ & Very Not Good & \multirow{5}{*}{3.6757} & \multirow{5}{*}{4} & \multirow{5}{*}{2} & \multirow{5}{*}{5} \\
\hline & & $12.7-18.2$ & 1 & $2.7 \%$ & Not good & & & & \\
\hline & & $18.3-23.8$ & 13 & $35.1 \%$ & Enough & & & & \\
\hline & & $23.9-29.4$ & 20 & $54.1 \%$ & Good & & & & \\
\hline & & $29.5-35.0$ & 3 & $8.1 \%$ & Very good & & & & \\
\hline
\end{tabular}


SMPN 8 Batanghari class VII A which was the most dominant with a good category of $43.2 \%$ as many as 16 people at an interval of
23.9 - 29.4 while class VII B was the most dominant with a good category of $35.1 \%$ as many as 13 people at an interval of $23.9-$

Table 7. Descriptions of student attitudes towards science subjects with fermentation material on indicators of interest in a career in science

\begin{tabular}{|c|c|c|c|c|c|c|c|c|c|}
\hline \multicolumn{2}{|c|}{ Student Response } & Interval & $\mathbf{F}$ & $\%$ & Category & Mean & Med & Min & Max \\
\hline \multirow{10}{*}{$\begin{array}{c}\text { SMPN } 8 \\
\text { Batanghari }\end{array}$} & \multirow{5}{*}{$\begin{array}{c}\text { VII } \\
\mathrm{A}\end{array}$} & $7.0-12.6$ & 0 & $0 \%$ & Very Not Good & \multirow{5}{*}{3.2432} & \multirow{5}{*}{3} & \multirow{5}{*}{2} & \multirow{5}{*}{4} \\
\hline & & $12.7-18.2$ & 5 & $13.5 \%$ & Not good & & & & \\
\hline & & $18.3-23.8$ & 18 & $48.6 \%$ & Enough & & & & \\
\hline & & $23.9-29.4$ & 14 & $37.8 \%$ & Good & & & & \\
\hline & & $29.5-35.0$ & 0 & $0 \%$ & Very good & & & & \\
\hline & \multirow{5}{*}{$\begin{array}{l}\text { VII } \\
\text { B }\end{array}$} & $7.0-12.6$ & 2 & $5.4 \%$ & Very Not Good & \multirow{5}{*}{3.2162} & \multirow{5}{*}{3} & \multirow{5}{*}{1} & \multirow{5}{*}{4} \\
\hline & & $12.7-18.2$ & 0 & $0 \%$ & Not good & & & & \\
\hline & & $18.3-23.8$ & 23 & $62.2 \%$ & Enough & & & & \\
\hline & & $23.9-29.4$ & 12 & $32.4 \%$ & Good & & & & \\
\hline & & $29.5-35.0$ & 0 & $0 \%$ & Very good & & & & \\
\hline \multirow{10}{*}{$\begin{array}{c}\text { MTsN } 6 \\
\text { Batanghari }\end{array}$} & \multirow{5}{*}{$\begin{array}{c}\text { VII } \\
\text { A }\end{array}$} & $7.0-12.6$ & 0 & $0 \%$ & Very Not Good & \multirow{5}{*}{3.5946} & \multirow{5}{*}{4} & \multirow{5}{*}{2} & \multirow{5}{*}{5} \\
\hline & & $12.7-18.2$ & 1 & $2.7 \%$ & Not good & & & & \\
\hline & & $18.3-23.8$ & 14 & $37.8 \%$ & Enough & & & & \\
\hline & & $23.9-29.4$ & 21 & $56.8 \%$ & Good & & & & \\
\hline & & $29.5-35.0$ & 1 & $2.7 \%$ & Very good & & & & \\
\hline & \multirow{5}{*}{$\begin{array}{c}\text { VII } \\
\text { B }\end{array}$} & $7.0-12.6$ & 0 & $0 \%$ & Very Not Good & \multirow{5}{*}{3.4865} & \multirow{5}{*}{4} & \multirow{5}{*}{2} & \multirow{5}{*}{5} \\
\hline & & $12.7-18.2$ & 4 & $10.8 \%$ & Not good & & & & \\
\hline & & $18.3-23.8$ & 13 & $35.1 \%$ & Enough & & & & \\
\hline & & $23.9-29.4$ & 18 & $48.6 \%$ & Good & & & & \\
\hline & & $29.5-35.0$ & 2 & $5.4 \%$ & Very good & & & & \\
\hline
\end{tabular}

29.4. At MTsN 6 Batanghari class VII A was the most dominant with a good category of $35.1 \%$ as many as 13 people at an interval of 23.9 - 29.4 while class VII B in a good category was $54.1 \%$ as many as 20 people at an interval of $23.9-29.4$. In the indicator of interest in a career in science at SMPN 8 Batanghari, class VII A is the most dominant with a sufficient category of $48.6 \%$ as many as 18 people with an interval of $18.3-23.8$ while class VII B is $62.2 \%$ with a sufficient category of 23 people in the interval 18.3 23.8. At MTsN 5 Batanghari, the most dominant class VII A was $56.8 \%$ as many as 21 people at intervals of $23.9-29.4$ while class VII B was $48.6 \%$ as many as 18 people at intervals of $23.9-29.4$.

This study is in line with research conducted by (Astalini et al., 2019) which tested descriptive tests, but in this study only use indicators Enjoyment of science lesson Analysis, Leisure interest in science and Carrer interest in science. while in this study, descriptive results were tested on the attitude variable using two indicators. The description of the results for the variable of student interest for grades VII A and VII B at SMPN 8 Batanghari and MTsN 6 Batanghari on indicators of attention in learning is shown in Table 8. 
Table 8. Descriptions of student interest in science subjects with fermentation material on indicators of attention in learning

\begin{tabular}{|c|c|c|c|c|c|c|c|c|c|}
\hline \multicolumn{2}{|c|}{ Student Response } & Interval & $\mathbf{F}$ & $\%$ & Category & Mean & Med & Min & Max \\
\hline \multirow{10}{*}{$\begin{array}{c}\text { SMPN } 8 \\
\text { Batanghari }\end{array}$} & \multirow{5}{*}{$\begin{array}{c}\text { VII } \\
\mathrm{A}\end{array}$} & $4.0-7.2$ & 0 & $0 \%$ & Very Not Good & \multirow{5}{*}{3,7838} & \multirow{5}{*}{4} & \multirow{5}{*}{2} & \multirow{5}{*}{5} \\
\hline & & $7.3-10.4$ & 2 & $5.4 \%$ & Not good & & & & \\
\hline & & $10.5-13.6$ & 13 & $35.1 \%$ & Enough & & & & \\
\hline & & $13.7-16.8$ & 13 & $35.1 \%$ & Good & & & & \\
\hline & & $16.9-20$ & 9 & $24.3 \%$ & Very good & & & & \\
\hline & \multirow{5}{*}{$\begin{array}{l}\text { VII } \\
\text { B }\end{array}$} & $4.0-7.2$ & 0 & $0 \%$ & Very Not Good & \multirow{5}{*}{3.8} & \multirow{5}{*}{4} & \multirow{5}{*}{2} & \multirow{5}{*}{5} \\
\hline & & $7.3-10.4$ & 1 & $2.9 \%$ & Not good & & & & \\
\hline & & $10.5-13.6$ & 14 & $20 \%$ & Enough & & & & \\
\hline & & $13.7-16.8$ & 11 & $31.4 \%$ & Good & & & & \\
\hline & & $16.9-20$ & 9 & $25.7 \%$ & Very good & & & & \\
\hline \multirow{10}{*}{$\begin{array}{l}\text { MTsN } 6 \\
\text { Batanghari }\end{array}$} & \multirow{5}{*}{$\begin{array}{c}\text { VII } \\
\text { A }\end{array}$} & $4.0-7.2$ & 0 & $0 \%$ & Very Not Good & \multirow{5}{*}{3.6944} & \multirow{5}{*}{3.5} & \multirow{5}{*}{2} & \multirow{5}{*}{5} \\
\hline & & $7.3-10.4$ & 3 & $5.6 \%$ & Not good & & & & \\
\hline & & $10.5-13.6$ & 16 & $44.4 \%$ & Enough & & & & \\
\hline & & $13.7-16.8$ & 9 & $25 \%$ & Good & & & & \\
\hline & & $16.9-20$ & 9 & $25 \%$ & Very good & & & & \\
\hline & \multirow{5}{*}{$\begin{array}{l}\text { VII } \\
\text { B }\end{array}$} & $4.0-7.2$ & 0 & $0 \%$ & Very Not Good & \multirow{5}{*}{3.7222} & \multirow{5}{*}{4} & \multirow{5}{*}{2} & \multirow{5}{*}{5} \\
\hline & & $7.3-10.4$ & 3 & $5.6 \%$ & Not good & & & & \\
\hline & & $10.5-13.6$ & 14 & $38.9 \%$ & Enough & & & & \\
\hline & & $13.7-16.8$ & 12 & $33.3 \%$ & Good & & & & \\
\hline & & $16.9-20$ & 8 & $22.2 \%$ & Very good & & & & \\
\hline
\end{tabular}

The description of the results for the variable of student interest in science subjects with fermentation material for grades VII A and VII B at SMPN 8 Batanghari and MTsN 6 Batanghari on the indicator of feeling happy is shown in Table 9.
In the results of the descriptive statistical test of the interest variable, there are two indicators. In the first indicator, namely attention in learning it was found that SMPN 8 Batanghari class VII A the most dominant is $35.1 \%$ with good and sufficient categories as

Table. 9 Descriptions of student interest in science subjects with fermentation material on indicators of feeling happy

\begin{tabular}{|c|c|c|c|c|c|c|c|c|c|}
\hline \multicolumn{2}{|c|}{ Student Response } & Interval & $\mathbf{F}$ & $\%$ & Category & Mean & Med & Min & Max \\
\hline \multirow{10}{*}{$\begin{array}{c}\text { SMPN } 8 \\
\text { Batanghari }\end{array}$} & \multirow{5}{*}{$\begin{array}{c}\text { VII } \\
\mathrm{A}\end{array}$} & $5-9$ & 0 & $0 \%$ & Very Not Good & \multirow{5}{*}{3.5833} & \multirow{5}{*}{3.5} & \multirow{5}{*}{2} & \multirow{5}{*}{5} \\
\hline & & $10-13$ & 3 & $5.6 \%$ & Not good & & & & \\
\hline & & $14-17$ & 16 & $44.4 \%$ & Enough & & & & \\
\hline & & $18-21$ & 13 & $36.1 \%$ & Good & & & & \\
\hline & & $22-25$ & 5 & $13.9 \%$ & Very good & & & & \\
\hline & \multirow{5}{*}{$\begin{array}{c}\text { VII } \\
\text { B }\end{array}$} & $5-9$ & 0 & $0 \%$ & Very Not Good & \multirow{5}{*}{3.5404} & \multirow{5}{*}{3} & \multirow{5}{*}{2} & \multirow{5}{*}{5} \\
\hline & & $10-13$ & 3 & $5.4 \%$ & Not good & & & & \\
\hline & & $14-17$ & 18 & $48.6 \%$ & Enough & & & & \\
\hline & & $18-21$ & 12 & $32.4 \%$ & Good & & & & \\
\hline & & $22-25$ & 5 & $13.5 \%$ & Very good & & & & \\
\hline
\end{tabular}




\begin{tabular}{|c|c|c|c|c|c|c|c|c|c|}
\hline \multirow{10}{*}{$\begin{array}{l}\text { MTsN } 6 \\
\text { Batanghari }\end{array}$} & \multirow{5}{*}{$\begin{array}{c}\text { VII } \\
\text { A }\end{array}$} & $5-9$ & 0 & $0 \%$ & Very Not Good & \multirow{5}{*}{3.5556} & \multirow{5}{*}{3} & \multirow{5}{*}{3} & \multirow{5}{*}{5} \\
\hline & & $10-13$ & 0 & $0 \%$ & Not good & & & & \\
\hline & & $14-17$ & 20 & $55.6 \%$ & Enough & & & & \\
\hline & & $18-21$ & 12 & $33.3 \%$ & Good & & & & \\
\hline & & $22-25$ & 5 & $11.1 \%$ & Very good & & & & \\
\hline & \multirow{5}{*}{$\begin{array}{l}\text { VII } \\
\text { B }\end{array}$} & $5-9$ & 0 & $0 \%$ & Very Not Good & \multirow{5}{*}{3.5946} & \multirow{5}{*}{3} & \multirow{5}{*}{3} & \multirow{5}{*}{5} \\
\hline & & $10-13$ & 0 & $0 \%$ & Not good & & & & \\
\hline & & $14-17$ & 19 & $51.4 \%$ & Enough & & & & \\
\hline & & $18-21$ & 14 & 37.85 & Good & & & & \\
\hline & & $22-25$ & 4 & $10.8 \%$ & Very good & & & & \\
\hline
\end{tabular}

many as 13 people at intervals of $13.7-16.8$ while class VII B was $31.4 \%$ with a good category as many as 11 people at intervals of 13.7 - 16.8. At MTsN 6 Batanghari class VII A was $44.4 \%$ with a sufficient category of 16 people at intervals of 10.5 - 13.6 while class VII B was $38.9 \%$ with a sufficient category of 1 person at intervals of $10.5-13,6$. In the indicator of feeling happy at SMPN 8 Batanghari, the most dominant class VII A is $44.4 \%$ with a sufficient category of 16 people at intervals of $14-17$ while class VII $B$ is $48.6 \%$ as many as 18 people at the same interval. At MTsN 6 Batanghari, the most dominant class VII A was $55.6 \%$ with a sufficient category of 20 people with an interval of 14-17 while class VII B was $51.4 \%$ with a sufficient category of 19 people at the same interval. This study is in line with research conducted by (Karina et al., 2017) which tested descriptive tests, but in this study only discuss interest in general without using any indicators. while in this study, descriptive results were tested on the interest variable using two indicators.

\section{Comparative analysis.}

In this assumption test, there are two tests that will be carried out, namely the normality test which serves to see whether the data is normally distributed or not, and also the linearity test which functions to see the linear relationship between the two variables to be tested. The assumption test on this data was carried out with the help of IBM SPSS Statistic 25. The Shapiro-Francia (SF) normality test is an important test in statistical modeling (Mbah \& Paothong, 2015).

Normality test is used to test whether the data is normally distributed or not (Saerang et al., 2014). The data requirements are said to be normally distributed if the value of sig. $>$ 0.05 . Homogeneity test is a test used to determine whether the variance of the data distribution is the same (homogeneous) or not the same (non-homogeneous). The data requirements are said to be homogeneous if the value of sig. $>0.05$. Linearity test is a test used to determine the form of the relationship between the independent variable or the dependent variable. The data conditions are said to be related if the value of sig. $<0.05$.

The description of the results for the normality test of students' attitudes and interests towards science subjects with fermentation material for grades VII A and VII $\mathrm{B}$ at SMPN 8 Batanghari and MTsN 6 Batanghari is shown in Table 10. The description of the results for the homogeneity test of students' attitudes and interests towards science subjects with fermentation material for grades VII A and VII B at SMPN 8 Batanghari and MTsN 6 Batanghari is shown in Table 10.

The description of the results for the 
Table 10. Descriptions of the normality test

\begin{tabular}{|c|c|c|c|c|}
\hline Variable & School & class & Sig. & Distribute \\
\hline \multirow{4}{*}{ Attitude } & \multirow{2}{*}{ SMPN 8 Batanghari } & VII A & 0.200 & Normal \\
\hline & & VII B & 0.200 & Normal \\
\hline & \multirow{2}{*}{ MTsN 6 Batanghari } & VII A & 0.200 & Normal \\
\hline & & VII B & 0.096 & Normal \\
\hline \multirow{4}{*}{ Interest } & \multirow{2}{*}{ SMPN 8 Batanghari } & VII A & 0.200 & Normal \\
\hline & & VII B & 0.089 & Normal \\
\hline & \multirow{2}{*}{ MTsN 6 Batanghari } & VII A & 0.200 & Normal \\
\hline & & VII B & 0.200 & Normal \\
\hline
\end{tabular}

Table 11. Descriptions of the homogeneity test

\begin{tabular}{|c|c|c|c|c|}
\hline Variable & School & class & Sig. & Distribute \\
\hline \multirow{4}{*}{ attitude } & \multirow{2}{*}{ SMPN 8 Batanghari } & VII A & \multirow{2}{*}{0.373} & \multirow{2}{*}{ Homogen } \\
\hline & & VII B & & \\
\hline & \multirow{2}{*}{ MTsN 6 Batanghari } & VII A & \multirow{2}{*}{0.834} & \multirow{2}{*}{ Homogen } \\
\hline & & VII B & & \\
\hline \multirow{4}{*}{ interest } & \multirow{2}{*}{ SMPN 8 Batanghari } & VII A & \multirow{2}{*}{0.363} & \multirow{2}{*}{ Homogen } \\
\hline & & VII B & & \\
\hline & \multirow{2}{*}{ MTsN 6 Batanghari } & VII A & \multirow{2}{*}{0.277} & \multirow{2}{*}{ Homogen } \\
\hline & & VII B & & \\
\hline
\end{tabular}

Table 12. Description of the results of the linearity test of students' attitudes and interests in science subjects

\begin{tabular}{cccc}
\hline Variabel & School & Sig. & distribute \\
\hline \multirow{2}{*}{ attitude*Interest } & SMPN 8 Batanghari & 0.012 & Linear \\
\cline { 2 - 4 } & MTsN 6 Batanghari & 0.013 & Linear \\
\hline
\end{tabular}

linearity test of students' attitudes and interests in science subjects with fermentation material at SMPN 8 Batanghari and MTsN 6 Batanghari is shown in Table 11.

In this hypothesis test, the tests carried out are $\mathrm{T}$ test and correlation test. The $\mathrm{t}$ test aims to determine whether the independent variable has an effect on the dependent variable while the correlation test aims to determine the relationship between process skills and the jigsaw model on velocity and discharge material. The description of the results for the T-test of students' attitudes and interests towards science subjects with fermentation material at SMPN 8 Batanghari and MTsN 6 Batanghari is shown in Table 13. The description of the results for the correlation test between students' attitudes and interests in science subjects with fermentation material at SMPN 8 Batanghari and MTsN 6 Batanghari is shown in Table 14.

Based on table 10, the normality test of students' attitudes towards science subjects with fermentation material for grades 
Table 13. T-test description of students' attitudes and interests towards science subjects

\begin{tabular}{|c|c|c|c|}
\hline Variabel & School & Class & Sig.(2-tailed) \\
\hline Attitude & \multirow{2}{*}{ SMPN 8 Batanghari } & $\begin{array}{l}\text { VII A } \\
\text { VII B }\end{array}$ & 0.037 \\
\hline Interest & & $\begin{array}{l}\text { VII A } \\
\text { VII B }\end{array}$ & 0.050 \\
\hline Attitude & \multirow{2}{*}{ MTsN 6 Batanghari } & $\begin{array}{l}\text { VII A } \\
\text { VII B }\end{array}$ & 0.034 \\
\hline Interest & & $\begin{array}{l}\text { VII A } \\
\text { VII B }\end{array}$ & 0.031 \\
\hline
\end{tabular}

Table 14. Description of the correlation test of students' attitudes and interests towards science

\begin{tabular}{|c|c|c|c|c|}
\hline School & Variable & Pearson Correlation & Sig.(2-tailed) & $N$ \\
\hline SMPN 8 Batanghari & $\begin{array}{c}\text { Attitude } \\
\text { Interest }\end{array}$ & 0.618 & 0.015 & 74 \\
\hline MTsN 6 Batanghari & $\begin{array}{c}\text { Attitude } \\
\text { Interest }\end{array}$ & 0.603 & 0.038 & 74 \\
\hline
\end{tabular}

VII $\mathrm{A}$ and VII $\mathrm{B}$ at SMPN 8 Batanghari obtained results based on the KolmogorovSmirnov test, a significance value of $0.200>$ from 0.05 and MTsN 6 Batanghari obtained results based on the Kolmogorov-Smirnov test value the significance of $0.200>$ from 0.05 , it can be concluded that the data is normally distributed. While the normality test of student interest in science subjects with fermentation material for grades VII A and VII B at SMPN 8 Batanghari, the results were obtained based on the Kolmogorov-Smirnov test, the significance value was $0.200>$ from 0.05 and MTsN 6 Batanghari obtained the results based on the Kolmogorov-Smirnov test, the significance value was $0.200>$ of 0.05 , it can be concluded that the data is normally distributed. Based on table 11, the homogeneity test of students' attitudes towards science subjects with fermentation material for grades VII A and VII B at SMPN 8 Batanghari was obtained, a significance value of $0.373>0.05$ while at MTsN 6 Batanghari obtained a significance value of $0.834>0.05$, it can be concluded that the data is homogeneous, and the homogeneity test of students' interest in science subjects with fermentation material for grades VII A and VII B at SMPN 8 Batanghari was obtained, a significance value of $0.363>$ 0.05 while at MTsN 6 Batanghari obtained a significance value of $0.277>0.05$, it can be concluded that the data is homogeneous. Based on table 12. linearity test of students' attitudes and interests in science subjects with fermented material at SMPN 8 Batanghari and MTsN 6 Batanghari obtained a significance value of $0.012<0.05$ and $0.013>0.05$, so it can be concluded that there is a linear relationship between students' attitudes and interests in subjects Science with fermentation material at SMPN 8 Batanghari and MTsN 6 Batanghari.

The data analysis of the hypothesis testing used in this study were: $T$ test and correlation test with the help of IBM SPSS Statistics 25. T-test was used to determine the relationship between two variables. To determine the correlation between scales, correlation 
analysis is used (Can \& Öztürk, 2019). The correlation test was carried out to determine the relationship between two variables, so that there were no dependent variables and independent variables in it (Tanti et al., 2021). Based on table 13 the $\mathrm{T}$ test of students' attitudes and interests towards science subjects with fermented material at SMPN 8 Batanghari and MTsN 6 Batanghari, the results of the $\mathrm{T}$ test for student attitudes at SMPN 8 Batanghari are sig. (2-tailed) $0.037<0.05$ while for Student interest in SMPN 8 Batanghari is sig. (2-tailed) 0.047 , so it can be concluded that there are differences in students' attitudes and interests towards science subjects and fermented materials at SMPN 8 Batanghari. for student attitudes at MTsN 6 Batanghari, namely the value of sig. (2-tailed) $0.034<0.05$ while for student interest at MTsN 6 Batanghari the value of sig. (2-tailed) 0.031 , it can be concluded that there are differences in students' attitudes and interests towards subjects IPA with fermented material at MTsN 6 Batanghari. Based on the table. 14 correlation tests of students' attitudes and interests towards science subjects with fermented material at SMPN 8 Batanghari and MTsN 6 Batanghari were obtained, the results of the correlation test were sig. (2-tailed) $<$ 0.05 , it can be concluded that there is a relationship between attitudes and students' interest in science subjects with fermented material at SMPN 8 Batanghari and MTsN 6 Batanghari with a Pearson correlation of 0.618 and 0.603 which means that at SMPN 8 Batanghari $61.8 \%$ the relationship between students' attitudes and interests can be categorized as good while the rest are related to other variables while at MTsN 6 Batanghari $60.3 \%$ the relationship between students' attitudes and interests can be categorized as good while the rest are related to other variables.
Previously, research on student attitudes towards science subjects had been conducted by (Astalini et al., 2018) The focus of this research is on 3 dimensions of attitude, namely the social implications of science, attitudes towards investigation and interest in a career in science. In this study, only 1 variable was used, namely student attitudes. Previously, research on the influence of interest on student learning outcomes has been carried out by (Nesi, 2018). In this study, it was found that interest in learning had an effect on student learning outcomes, and this study only used the variable of interest.

This research was conducted with the aim of knowing the comparison of students' attitudes towards science subjects, knowing the comparison of students' interest in science subjects with fermented material, and knowing the relationship between students' attitudes and interests in science subjects with fermented material. Students' attitudes and interests towards science subjects are important to study because students' attitudes and interests have no small influence on success, increase student learning outcomes, and affect student performance. Attitudes and interests are very important because the teacher can know that each student responds to science learning with an indication that students reject or accept science learning in students.

This study has many weaknesses due to the limitations of the author. These weaknesses include that the samples used in this study were only conducted at SMPN 8 Batanghari and MTsN 6 Batanghari grades VII A and VII B, so the results obtained might make a difference if they were carried out in other schools or classes. The data collection method used in this study only used questionnaire data, and the variables studied in this study were only variables of attitude and interest in science subjects. 


\section{CONCLUSIONS}

Based on the results of hypothesis testing, research testing and data analysis, the conclusions of this study were 74 students' attitudes towards science lessons from 2 classes, namely class VII A as many as 20 girls and 17 boys and VII B as many as 20 girls and 17 boys. male. Then the interest sample was 74 from 2 classes, namely VII A as many as 20 female students and 17 male students and VII $\mathrm{B}$ as many as 20 female students and 17 male students. This research was conducted at SMPN 8 Batanghari and MTsN 6 Batanghari. Based on the T-test of students' attitudes and interests towards science subjects with fermented material, the results of the T-test were obtained, namely the value of sig. (2-tailed $<0.05$, it can be concluded that there are differences in students' attitudes and interests towards science subjects with fermented material at SMPN 8 Batanghari and MTsN Batanghari 6. Based on the results of the correlation test between students' attitudes and interest in science subjects with fermented material obtained, the results of the correlation test are sig.(2-tailed) $<0.05$ then, it can be concluded that there is a relationship between attitudes and students' interest in science subjects with fermented material at SMPN 8 Batanghari and MTsN Batanghari 6. The limitation of this study is that the sample used in this study was only conducted at SMPN 8 Batanghari and MTsN 6 Batanghari class VII $\mathrm{A}$ and VII B, so the results obtained may make a difference if it is carried out in other schools or classes Data collection methods used in the study This n only uses questionnaire data, and the variables studied in this study are only variables of attitudes and interests in science subjects. With the research on students' attitudes and interests towards science subjects with fermented material, the researchers hope that in the future there will be research on variables other than students' attitudes and interests as well as on other materials.

\section{REFERENCES}

Alan, U. F., \& Afriansyah, E. A. (2017). Kemampuan Pemahaman Matematis Siswa Melalui Model Pembelajaran Auditory Intellectualy Repetition Dan Problem Based Learning[Students' Mathematical Understanding Ability Through Auditory Intellectually Repetition Learning Model and Problem Based Learning]. Jurnal Pendidikan Matematika, 11(1).67-78.

Astalini, A., Kurniawan, D. A., \& Sumaryanti, S. (2018). Sikap Siswa Terhadap Pelajaran Fisika di SMAN Kabupaten Batanghari[Students' Attitudes towards Physics Lessons at SMAN Batanghari Regency].Jurnal Ilmu Pendidikan Fisika.

Astalini, Kurniawan, D. A., Darmaji, Putri, A. D., \& Nawangsih, R. (2019). Identifiy student ' $\mathrm{s}$ attitude towards the subject of natural science. 13(3), 386-394.

Astri, M., Nikensari, S. I., \& Kuncara W., H. (2013). Pengaruh Pengeluaran Pemerintah Daerah Pada Sektor Pendidikan Dan Kesehatan Terhadap Indeks Pembangunan Manusia Di Indonesia[The Effect of Local Government Expenditures on the Education and Health Sector on the Human Development Index in Indonesia]. Jurnal Pendidikan Ekonomi Dan Bisnis, 1(1), 77.

Astuti, L. I. N. S. (2017). Penguasaan Konsep IPA Ditinjau Dari Konsep Diri[Mastery of Science Concepts Seen from SelfConcept]. Formatif/ : Jurnal Ilmiah 
304 | Jurnal Pendidikan Progresif, Vol. 11, No. 2, pp. 290-308, August 2021

Pendidikan MIPA, 7(1), 40-48.

Can, ${ }^{\text {a }}$, \& Öztürk, G. (2019). Determination of pre-service science teachers' attitudes towards reading science texts. International Journal of Evaluation and Research in Education, 8(1), 181188.

Cooper, G., \& Berry, A. (2020). Demographic predictors of senior secondary participation in biology, physics, chemistry and earth/space sciences: students' access to cultural, social and science capital. In International Journal of Science Education (Vol. 42, Issue 1). Huta Publisher.

Da Silva, P. R., De Andrade, M. A. B. S., \& De Andrade Caldeira, A. M. (2015). Biology teachers conceptions of the diversity of life and the historical development of evolutionary concepts. Journal of Biological Education, 49(1), $3-21$.

Dewi, V. P., Doyan, A., \& Soeprianto, H. (2017). Pengaruh model penemuan terbimbing terhadap keterampilan proses sains ditinjau dari sikap ilmiah pada pembelajaran ipa[The influence of the guided discovery model on science process skills in terms of scientific attitudes in science learning]. Jurnal Penelitian Pendidikan IPA.

Duygu, D. C., Alki ${ }^{\circ}$, N., \& Ozkan-Yildirim, S. (2018). A structural model for students' adoption of Learning Management Systems: An empirical investigation in the higher education context. Educational Technology and Society, 21(2), 13-27.

Fauziyah, S., \& Triyono, M. B. (2020). Pengaruh E-Learning Edmodo Dengan Model Blended Learning Terhadap Minat Belajar[The Effect of Edmodo's
E-Learning With Blended Learning Model on Interest in Learning]. Jurnal Kependidikan: Penelitian Inovasi Pembelajaran, 4(1), 112-124.

Fellner, K. D. (2018). Embodying Decoloniality: Indigenizing Curriculum and Pedagogy. American Journal of Community Psychology, 62(3-4), 283293.

Furqaani, A. R., Khairunnisa, A., Kholifah, Sari, N. K., Hadi, N., \& Yulianti, S. (2017). new edition big book biologi sma/ma kelas x, xi, \& xii. Penerbit Cmedia Imprint Kawan Pustaka.

Giorgi, A. (2019). Psychology as a human science: A phenomenologically based approach. University Professors Press.

Girindra Putri Ardana Reswari. (2018). Teaching English in the KTSP Curriculum and 2013 Curriculum Simultaneously: A Case Study of "A Senior High School in Semarang", Central Java, Indonesia. Journal of Materials Processing Technology, 1(1), $1-8$.

Hidayati, N., Rahmawati, A. Y., Khomah, I., \& Abdullah, A. A. (2020). Identifikasi Etnomatsains $p$ ada Tradisi Gunungan di Kraton Yogyakarta[Identification of Ethnomatscience in the Gunungan Tradition in the Yogyakarta Palace]. 4(3), 52-59.

Ilmu, T. kompas. (2019). Rumus Pocket Biologi SMA Kelas X, XI, XII. Gramedia widiasarana indonesia.

Imaduddin, M., \& Khafidin, Z. (2018). Ayo Belajar IPA dari Ulama: Pembelajaran Berbasis Socio-Scientific Issues di Abad ke-21[Let's Learn Science from Ulama: Learning Based on SocioScientific Issues in the 21 st Century]. In Thabiea/ : Journal of Natural Science 
Teaching. 1(2)

Jannah, M., Biologi, P. P., Makassar, U. M., \& Rahayu, M. (2021). Pengaruh pembelajaran online berbantuan google classroom terhadap hasil belajar siswa[The effect of online learning assisted by google classroom on student learning outcomes]. 1(1), 7584.

Karina, R. M., Syafrina, A., \& Habibah, S. (2017). Hubungan antara minat belajar dengan hasil belajar siswa dalam mata pelajaran ipa pada kelas $v$ sd negeri garot geuceu aceh besar[The relationship between interest in learning and student learning outcomes in science subjects in class V SD Negeri Garot Geuceu, Aceh Besar]. 2(1), 6177.

Kawet, R. S. . (2017). Pengaruh Metode Pembelajaran Dan Minat Belajar Mahasiswa Terhadap Hasil Belajar Manajemen Konstruksi[The Influence of Learning Methods and Student Interests on Learning Outcomes of Construction Management]. Jurnal Teknologi Pendidikan, 19(3), 224.

Kelleher, J. D., \& Tierney, B. (2018). Data Scince. The MIT Press.

Kumar, G., Mathimani, T., Rene, E. R., \& Pugazhendhi, A. (2019). Application of nanotechnology in dark fermentation for enhanced biohydrogen production using inorganic nanoparticles. International Journal of Hydrogen Energy, 44(26).

Kurniawan, D. A. (2021). Literatur Review/ : Penerapan Sintaks Model Pembelajaran Problem Solving Pada Kurikulum 2013[Literature Review: Application of Problem Solving Learning Model Syntax in the 2013 Curriculum]. 5(1), 147-153.
Kurniawan, D. A., Astalini, A., \& Anggraini, L. (2018). Evaluasi sikap siswa SMP terhadap IPA di Kabupaten Muaro Jambi[Evaluation of junior high school students' attitudes towards science in Muaro Jambi Regency]. Jurnal Ilmiah Didaktika.

Kustijono, R., \& Wiwin HM, E. (2014). Pandangan Guru Terhadap Pelaksanaan Kurikulum 2013 Dalam Pembelajaran Fisika Smk Di Kota Surabaya[Teacher's Views on the Implementation of the 2013 Curriculum in Vocational Physics Learning in the City of Surabaya]. Jurnal Penelitian Fisika Dan Aplikasinya, 4(1), 1.

Loudon, G. (2019). Integrating ideas from design disciplines into the STEM curricula. Higher Education Pedagogies, 4(1), 284-286.

Maison, Astalini, Kurniawan, D. A., \& Sholihah, L. R. (2018). Deskripsi Sikap Siswa Sma Negeri Pada Mata Pelajaran Fisika[Description of the Attitude of State High School Students in Physics Subjects]. Jurnal Eduasains, 10(1), 160-167.

Maison, M., Kurniawan, D. A., \& Pratiwi, N. I. S. (2020). Pendidikan sains di sekolah menengah pertama perkotaan: Bagaimana sikap dan keaktifan belajar siswa terhadap sains? [ Science education in urban junior high schools: What are students' attitudes and learning activities towards science?]. Jurnal Inovasi Pendidikan IPA, 6(2), 135-145.

Maknun, D., Gloria, R. Y., \& Muzakki, J. A. (2020). Keterampilan meneliti yang dimiliki mahasiswa prodi pendidikan biologi se-wilayah III Cirebon[Research skills possessed by Biology Education Study Program 
students throughout the region III Cirebon]. Jurnal Inovasi Pendidikan IPA, 6(1), 39-47.

Meganingtyas, B. R., Winarni, R., \& Murwaningsih, T. (2019). The Effect of Using Course Review Horay and Talking Stick Learning Methods Towards Social Science Learning Result Reviewed From Learning Interest. International Journal of Educational Research Review, 190-197.

Muchson, M. (2017). Statistik Deskriptif.Guepedia. Guepedia.

Nasution, L. M. (2017). Statistik deksriptif. Journal of the American Chemical Society.

Nasution, R. H., Hapidin, H., \& Fridani, L. (2020). Pengaruh Pembelajaran ICT dan Minat Belajar terhadap Kesiapan Membaca Anak Usia Dini[The Influence of ICT Learning and Learning Interest on Early Childhood Reading Readiness]. Jurnal Obsesi/ : Jurnal Pendidikan Anak Usia Dini, 4(2), 733.

Nenotaek, B., Sujadi, I., \& Subanti, S. (2019). The Difficulties in Implementing Scientific Approach for Mathematics Learning. International Journal of Educational Research Review.

Novalinda, R., Jalinus, N., \& Jama, J. (2020). Evaluasi Penerapan Kurikulum 2013 di SMK Negeri 1 Payakumbuh[Evaluation of 2013 Curriculum Implementation at SMK Negeri 1 Payakumbuh ].14(1).

Nugroho, U. (2018). Metodologi penelitian kuantitatif pendidikan jasmani[Physical education quantitative research methodology]. CV. Sarnu Untuung.

Nur Laila, \& Eriyanto, E. (2020). Penerapan Model Pembelajaran Langsung untuk Meningkatkan Hasil Belajar Siswa
Materi Shalat Berjamaah Kelas VII[Application of Direct Learning Model to Improve Student Learning Outcomes for Class VII Congregational Prayers]. Jurnal Pendidikan Islam Indonesia, 4(2), 203-214.

Parker, K. (2019). The Growing Partisan Divide in Views of Higher Education. Pew Research Center, 1-7.

Permatasari, B. D., Gunarhadi, \& Riyadi. (2019). The influence of problem based learning towards social science learning outcomes viewed from learning interest. International Journal of Evaluation and Research in Education, 8(1), 3946.

Prajapati, R., Sharma, B., \& Sharma, D. (2017). Significance Of Life Skills Education. 10(1), 1-6.

Pramesti, G. (2018). Mahir Mengolah data Penelitian Dengan Spss 25[Proficient in Processing Research Data With Spss 25]. elex media.

Putra, D. S., Lumbantoruan, A., \& Samosir, S. C. (2019). Deskripsi Sikap Siswa: Adopsi Sikap Ilmiah, Ketertarikan Memperbanyak Waktu Belajar Fisika dan Ketertarikan Berkarir di Bidang Fisika[Description of Student Attitudes: Adoption of Scientific Attitude, Interest in Increasing Time to Study Physics and Interest in a Career in Physics]. Tarbiyah/ : Jurnal Ilmiah Kependidikan.

Rahayu, A., \& Romadona, D. D. (2020). Deskripsi Implikasi Sosial dari Fisika , Sikap Terhadap Penyelidikan dalam Fisika dan Adopsi dari Sikap Ilmiah[Description of the Social Implications of Physics, Attitudes to Investigations in Physics and the Adoption of Scientific Attitudes ]. 1(1). 
Rahmawati, F. (2018). Kecenderungan Pergeseran Pendidikan Agama Islam di Indonesia Pada Era Disrupsi[Trends in Shifting Islamic Religious Education in Indonesia in the Era of Disruption]. TADRIS: Jurnal Pendidikan Islam, 13(2).

Rasyad, R. (2003). Metode Statistik Deskriptif[Descriptive Statistical Method ]. Grasindo.

Richardo, R., \& Richardo, R. (2016). Peran Ethnomatematika dalam Penerapan Pembelajaran Matematika[The Role of Ethnomathematics in the Application of Mathematics Learning]. 2(2), 118-125.

Saerang, I., Tommy, P., \& Christiano, M. (2014). Analisis Terhadap Rasio-rasio Keuangan Untuk Mengukur Profitabilitas Pada Bank-bank Swasta Yang Go Public Di Bursa Efek Indonesia[Analysis of Financial Ratios to Measure Profitability in Private Banks That Go Public on the Indonesia Stock Exchange]. Jurnal Riset Ekonomi, Manajemen, Bisnis Dan Akuntansi, 2(4), 817-830.

Santoso, S. (2019). Menguasai SPSS versi 2 [Mastering SPSS version 2]. Elex Media Komputindo.

Sofyan, F. A. (2019). Implementasi Hots Pada Kurikulum 2013[Implementation of Hots in the 2013 Curriculum] Inventa, 3(1), $1-9$.

Soleh, \& Zainiyati, H. S. (2020). Does Motivation, Personality and Environment Influence Enthusiasm of Generation $\mathrm{Z}$ to Contuining Study to Higher Education? International Journal of Educational Research Review, 287-295.

Sulfemi, W. B., \& Luthfianti, T. (2019). Asosiatiflayanan tenaga perpustakaan sekolah dengan motivasi membaca siswa di kabupaten bogor[Association of school librarian services with students' motivation to read in Bogor district]. Jurnal Ilmiah Edutecno, 19(106), 1-10.

Susanti, N., \& Djukri, D. (2018). Pengembangan modul biologi materi pokok ekosistem berbasis aktivitas siswa di pondok pesantren untuk menanamkan sikap spiritual dan kemandirian siswa Developing a biology module in ecosystem subject based o n student' $s$ activity at islamic boarding school[Developing a biology module in ecosystem subject based on student activities in Islamic boarding schools to instill a spiritual attitude and independence in students Developing a biology module in ecosystem subject based on student' s activity at Islamic boarding school]. Jornal Inovasi Pendidikan IPA, 4(1), 66.

Susilowati, S. (2017). Pengembangan Bahan Ajar IPA Terintegrasi Nilai Islam untuk Meningkatkan Sikap dan Prestasi Belajar IPA Siswa[Development of Islamic Values Integrated Science Teaching Materials to Improve Students' Science Learning Attitudes and Achievements ]. Jurnal Inovasi Pendidikan IPA, 3(1), 78.

Syukri, I. I. F., Rizal, S. S., \& Al Hamdani, M. D. (2019). Pengaruh Kegiatan Keagamaan terhadap Kualitas Pendidikan[The Influence of Religious Activities on the Quality of Education]. Jurnal Penelitian Pendidikan Islam, 7(1), 17.

Tamjid, E. (2018). Three-dimensional polycaprolactone-bioactive glass composite scaffolds: Effect of particle size and volume fraction on mechanical properties and in vitro cellular behavior. 
308 | Jurnal Pendidikan Progresif, Vol. 11, No. 2, pp. 290-308, August 2021

International Journal of Polymeric Materials and Polymeric Biomaterials. Tanti, T., Kurniawan, D. A., \& Ningsi, A. P. (2020). Description of students' science process skills on density material. Jurnal Inovasi Pendidikan IPA.

Tri Pudji Astuti. (2019). Model Problem Based Learning dengan Mind Mapping dalam Pembelajaran IPA Abad 21[Problem Based Learning Model with Mind Mapping in 21st Century Science Learning]. Proceeding of Biology Education, 3(1), 64-73.

Utaminingsih, R., Rahayu, A., \& Andini, D. W. (2018). Pengembangan RPP IPA sekolah dasar berbasis problem-based learning untuk siswa learning disabilities Development of primary school natural science lesson plan based on problem-based learning for learning disabilities students [Development of primary school science lesson plans based on problem-based learning for students with learning disabilities Development of primary school natural science lesson plans based on problem-based learning for learning disabilities students]. Jurnal Inovasi Pendidikan IPA, 4(2), 191-202. Wahyuni, M. (2020). Statistik Deskriptif untuk penelitian olah data manual dan SPSS Versi 25 [Descriptive Statistics for manual data processing research and SPSS Version 25].Bintang Pustaka Madani.

Wibowo, A. (2017). Pengaruh pendekatan pembelajaran matematika realistik dan saintifik terhadap prestasi belajar, kemampuan penalaran matematis dan minat belajar [The effect of realistic and scientific mathematics learning approach on learning achievement, mathematical reasoning ability and interest in learning]. Jurnal Riset Pendidikan Matematika, 4(1), 1.

Wulandari, A. (2020). Implementation of the 2013 Curriculum Based on a Scientific Approach (Case Study at SD Cluster II Kintamani). International Journal of Elementary Education, 4(3).

Yuliati, Y., \& Lestari, I. (2019). Penerapan model creative problem solving untuk meningkatkan hasil belajar siswa pada pembelajaran ilmu pengetahuan alam di sekolah dasar[ Application of creative problem solving models to improve student learning outcomes in natural science learning in elementary schools]. Jurnal Cakrawala Pendas, 5(2), 112. 